\title{
EDITORIAL
}

\section{MILLENNIUM DEVELOPMENT GOALS: LESSONS LEARNT AND THE WAY FORWARD}

\author{
Abraham Haileamlak (MD), Editor-in-Chief
}

DOI: http://dx.doi.org/10.4314/ejhs.v24i4.1

The Millennium Development Goals (MDGs) agenda crafted in 2001 targeting prominent challenges the world facing. These are eight international development goals to be achieved by 2015 addressing poverty, hunger, maternal and child mortality, communicable disease, education, gender inequality, environmental damage and the global partnership. This framework has laid ground by setting quantitative and time-bound targets despite variability among countries capability and starting baselines.

Though irregular, the MDGs announcement have raised governments' commitment and public awareness that helped mobilize action in support of poverty eradication efforts across the world. However, since the ongoing interventions are variable and slow, some of the targets may remain unreachable. Most efforts worldwide have focused on maternal and child health and communicable diseases with limited attention to other targets. As a result, as the deadline for the MDGs comes closer, some countries are on track of achieving some of the targets, but, some of the world's low income countries are being left behind in efforts to meet the targets.

Several factors contributed for these irregularities. The MDGs were developed somehow in a closed-door with little or no consultation among developing countries, civil society and other stakeholders which resulted in poor ownership by civil society and national governments. Furthermore, they focus on sub-sections of certain social sectors and selective human needs. In some, the targets are not ambitious enough, in others, they are unfeasible. The other failure has been a lack of accountability for meeting goals in an equitable, transparent and participatory manner that promotes sustained institutional change.

The UN decided on the need of setting a more ambitious development agenda to accede to the MDGs. The goals and targets beyond 2015 must consider lessons from the current set of MDGs. The first step is to have broad consultations on the future goals by creating fora for local, national, and regional debate involving key stakeholders, including governments, civil societies, private sector and development agencies.

Accordingly, the post-2015 agenda is now under discussion. The new targets, whatever the nomenclature is, should reflect today's political situation, health and environmental challenges, and an all-inclusive, inter-sectoral and accountable approach should be adopted. Nations must agree on a new set of goals and adapt at the national level to reflect each country's specific capacities, constraints and challenges. In addition to customizing the targets, countries should be assessed on their progress and the efforts they are making to expand opportunities to live in freedom and dignity for all, without discrimination.

The current issue (Vol. 24, No 4), the fifth issue (four regular and one special) in the leap of EJHS to a quarterly publication, contains ten original articles on varied subjects and three case reports focusing on different areas. I invite readers to read through these articles and appreciate or utilize the contents. I also encourage readers to forward comments and suggestions.

\section{REFERENCES}

1. Jacques Baudouy. Partners for Health: MDG and beyond. The 6th Global Conference on Health Promotion Bangkok, Thailand, 7-11 August 2005.

2. UN. Lessons Learned from MDG Monitoring From A Statistical Perspective Report of the Task Team on Lessons Learned from MDG Monitoring of the IAEG-MDG. United Nations, March 2013.

3. Marta Lomazzi, Bettina Borisch, Ulrich Laaser. The Millennium Development Goals: experiences, achievements and what's next. Global Health Action, 2014;7:23695 - http://dx.doi.org/10.3402/ gha.v7.23695.

4. Global Development. Learning the lessons of the MDGs: second time round, let's get it right. http://www.theguardian.com/global-development/poverty-matters/2011/aug/30/millennium-development-goalsafter-2015.

5. Nicole Bates-Eamer, Barry Carin, Min Ha Lee and Wonhyuk Lim, Mukesh Kapila. Post-2015 Development Agenda: Goals, Targets and Indicators. Special report. CIGI. October 19, 2012.

6. Institute of Development Agencies. Millennium Development Goals (MDGs) and Post 2015 Agenda. http://www.ids.ac.uk/idsresearch/millennium-development-goals-mdgs-and-post-2015-agenda 